\title{
Correction: Wang, J.S., et al. Effects of Nitrogen Addition on Leaf Decomposition of Single-Species and Litter Mixture in Pinus tabulaeformis Forests. Forests, 2015, 6, 4462-4476
}

\author{
Jinsong Wang ${ }^{1,2}$, Wensheng Bu ${ }^{3}$, Bo Zhao ${ }^{1}$, Xiuhai Zhao ${ }^{1, *}$, Chunyu Zhang ${ }^{1}$, Juan Fan ${ }^{1}$ and \\ Klaus V. Gadow 4,5 \\ 1 Key Laboratory for Forest Resources \& Ecosystem Processes, Beijing Forestry University, \\ Beijing 100083, China; wangjinsong@caf.ac.cn (J.W.); job0824@163.com (B.Z.); \\ zcy_0520@163.com (C.Z.); magnolia-fanjuan@163.com (J.F.) \\ 2 Research Institute of Forest Ecology, Environment and Protection, Chinese Academy of Forestry, \\ Beijing 100091, China \\ 3 College of Forestry, Jiangxi Agricultural University, Nanchang 330045, China; bws2007@163.com \\ 4 Department of Forestry and Wood Technology, University of Stellenbosch, Stellenbosch, South Africa \\ 5 Faculty of Forestry and Forest Ecology, Georg-August-University Göttingen, Büsgenweg 5, \\ Göttingen D-37077, Germany; kgadow@gwdg.de \\ * Correspondence: zhaoxh@bjfu.edu.cn; Tel.: +86-010-6233-6189; Fax: +86-010-6233-8197
}

Academic Editor: Eric J. Jokela

Received: 27 May 2016; Accepted: 6 June 2016; Published: 14 June 2016

We discovered typographical errors in two sentences and, therefore, changes are needed to our published manuscript [1]. In the Abstract and Section 2.2 of the Experimental Design, four $\mathrm{N}$ addition treatments should have been $50 \mathrm{~kg} \mathrm{~N}^{-1}$. year ${ }^{-1}$ instead of $5 \mathrm{~kg} \mathrm{~N}^{-1}$. year ${ }^{-1}$ for the low-N treatment, $100 \mathrm{~kg} \mathrm{~N}$ ha $^{-1}$. year ${ }^{-1}$ instead of $10 \mathrm{~kg} \mathrm{~N}^{-1}$. year ${ }^{-1}$ for the medium- $\mathrm{N}$ treatment and $150 \mathrm{~kg} \mathrm{~N} \mathrm{ha}^{-1}$. year ${ }^{-1}$ instead of $15 \mathrm{~kg} \mathrm{~N} \mathrm{ha}^{-1}$. year ${ }^{-1}$ for the high- $\mathrm{N}$ treatment. The sentence in the Abstract should read "Four $\mathrm{N}$ addition treatments, i.e., control (N0: $0 \mathrm{~kg} \mathrm{~N} \mathrm{ha}^{-1} \cdot \mathrm{year}^{-1}$ ),

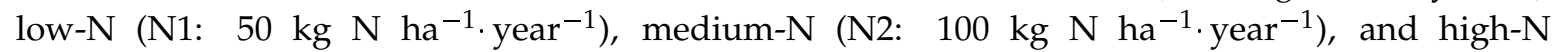
(N3: $150 \mathrm{~kg} \mathrm{~N} \mathrm{ha}^{-1}$. year ${ }^{-1}$ ), were applied starting May 2010"; and the sentence in the Section 2.2 of the Experimental Design should read "four treatments (each treatment with three replicates) with $\mathrm{N}$ addition were investigated in the plots: control (N0: $\left.0 \mathrm{~kg} \mathrm{~N}^{-1} \cdot \mathrm{year}^{-1}\right)$, low-N (N1: $50 \mathrm{~kg} \mathrm{~N}^{-1} \cdot$ year $^{-1}$ ), medium-N (N2: $100 \mathrm{~kg} \mathrm{~N} \mathrm{ha}^{-1}$. year $\left.{ }^{-1}\right)$, and high-N (N3: $150 \mathrm{~kg} \mathrm{~N}$ ha $^{-1} \cdot$ year $\left.^{-1}\right)^{\prime \prime}$. The changes will not impact the conclusion of the original version.

The authors would like to apologize for any inconvenience caused to the readers by these changes. The manuscript will be updated and the original will remain available on the article webpage.

\section{Reference}

1. Wang, J.S.; Bu, W.S.; Zhao, B.; Zhao, X.H.; Zhang, C.Y.; Fan, J.; Gadow, K.V. Effects of Nitrogen Addition on Leaf Decomposition of Single-Species and Litter Mixture in Pinus tabulaeformis Forests. Forests 2015, 6, 4462-4476. [CrossRef]

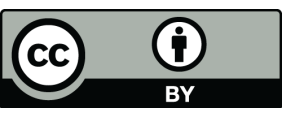

(C) 2016 by the authors; licensee MDPI, Basel, Switzerland. This article is an open access article distributed under the terms and conditions of the Creative Commons Attribution (CC-BY) license (http://creativecommons.org/licenses/by/4.0/). 